GEOLOGICA BALCANICA, 49 (1), Sofia, April 2020, pp. 79-83.

\title{
Bibliographia balcanica
}

Bibliographies of references devoted to the geology of the Balkan Peninsula have periodically been annotated in Geologica Balcanica in earlier times, since many publications were either of a limited distribution or printed in native languages of the Balkan authors and, therefore, could not reach a wider international audience. At these times, the Editorial Board of Geologica Balcanica believed that "Bibliographia balcanica" would help readers of our journal stay informed about the news and achievements in the geology of the Balkan countries. Despite the rapid development of communication technologies over the last few decades, there are numerous works from Bulgaria that still remain poorly known both in our country and elsewhere. In this issue, we have compiled a reference list of Bulgarian doctoral dissertations in the field of geology defended in the last twenty years. As a rule, doctoral dissertations in Bulgaria remain unpublished and their authors often publish their results in research articles only partially. We are aware that the present bibliography may be incomplete and all works are written in Bulgarian; nevertheless, we believe that the references listed herein will be useful to our readers, since they would give them an idea about what contributions have been made during the last two decades.

\section{DSc theses (2017-2002)}

Pimpirev, H.Tz. 2017. Stratigraphy and geological evolution of Livingston Island, Antarctica during the Cretaceous Period. DSc thesis, Sofia University "St Kliment Ohridski", 159 pp. Summary.

Bonev, N.G. 2011. Regional geology and geodynamic evolution of the eastern Circum-Rhodope Belt, Bulgaria-Greece. DSc thesis, Sofia University "St Kliment Ohridski", 181 pp. Summary.

Kostov, R.I. 2010. Mineralogy of artifacts (from the Neolithic to the Antiquity period) from Bulgaria and their significance in the history of gemmology. DSc thesis, University of Mining and Geology "St Ivan Rilski”, Sofia, vol. I-II, 577 pp.

Stoykova, K.H. 2008. Paleocene and lower Eocene stratigraphy of North Bulgaria based on calcareous nannofossils. DSc thesis, Geological Institute, Bulgarian Academy of Sciences, Sofia, $338 \mathrm{pp}$.

Sinnyovsky, D. 2007. Biostratigraphy of the Upper Cretaceous of Bulgaria based on calcareous nannoplankton. DSc thesis, University of Mining and Geology "St Ivan Rilski”, Sofia, $268 \mathrm{pp}$.

Evlogiev, Y. 2006. The Pleistocene and the Holocene in the Danube plain. DSc thesis, Geological Institute, Bulgarian Academy of Sciences, Sofia, 263 pp.

Marchev, P.G. 2006. Genetic models of the Paleogene hydrothermal ore deposits of the Eastern and Central Rhodopes on the bases of precise ${ }^{40} \mathrm{Ar}{ }^{\beta 9} \mathrm{Ar}$ geochronology and $\mathrm{Sr}$ and $\mathrm{Pb}$ isotopic geochemistry. DSc thesis, Geological Institute, Bulgarian Academy of Sciences, Sofia, 167 pp.

Vassilev, S.V. 2005. Mineralogy and geochemistry of coals and their combustion solid waste products. DSc thesis, Institute of Mineralogy and Crystallography, Bulgarian Academy of Sciences, Sofia, vol. I, 263 pp.; vol. II, 440 pp.
Bonev, I.K. 2002. Mineral genesis in the hydrothermal oreforming system of the Madan vein and replacement leadzinc deposits. DSc thesis, Geological Institute, Bulgarian Academy of Sciences, Sofia, 167 pp.

\section{PhD theses (2020-2000)}

\section{0}

Marinova, K.Y. 2020. Mineralogical-petrographic investigation of artifacts from cult sites (second half of II millennium $B C-I$ millennium BC) in the Eastern Rhodopes, South Bulgaria. PhD thesis, University of Mining and Geology "St Ivan Rilski”, Sofia, 210 pp. Full text.

Toshev, M.H. 2020. High-resolution processing of seismic data with preservation of true amplitude ratio allowing $A V O$ analysis of extracted properties for geological survey purposes. PhD thesis, University of Mining and Geology "St Ivan Rilski”, Sofia, 375 pp. Full text.

\section{9}

Atanasova, N.A. 2019. Establishing a database for the assessment and management of the geological heritage in Southwest Rila for the purposes of geopark Rila. PhD thesis, University of Mining and Geology "St Ivan Rilski”, Sofia, 189 pp. Full text.

Berov, L.B. 2019. Hydrogeological characterization and development of conceptual models of mineral water bodies in the Kyustendil hydrogeothermal system. $\mathrm{PhD}$ thesis, University of Mining and Geology "St Ivan Rilski”, Sofia, 294 pp. Full text.

Karibayev, A.A. 2019. Development and research of an effective technology for thermal acid treatment of the bottom 
hole zone of the reservoir for increasing the intensity of extraction. PhD thesis, University of Mining and Geology "St Ivan Rilski”, Sofia, 161 pp. Full text.

Kolev, S.N. 2019. Current state and prediction of radionuclide contamination of groundwater and surface water in the region of "Eleshnitsa" uranium mine. $\mathrm{PhD}$ thesis, Geological Institute, Bulgarian Academy of Sciences, Sofia, 120 pp. Full text.

Lakov, A.V. 2019. Rock slope stability in openpit mines and quarries. PhD thesis, University of Mining and Geology "St Ivan Rilski”, Sofia, 270 pp. Full text.

Lyutov, G. 2020. Mineral associations and evolution of the ore-forming processes in the Sedefche $\mathrm{Au}$-Ag deposit. $\mathrm{PhD}$ thesis, University of Mining and Geology "St Ivan Rilski”, Sofia, 121 pp.

Meracheva, G.G. 2019. Hydrocarbon potential of the southeast part of the Upper Thrace Depression. $\mathrm{PhD}$ thesis, University of Mining and Geology "St Ivan Rilski”, Sofia, $156 \mathrm{pp}$. Full text.

Popova, I. 2019. Protection of buildings and facilities in the surrounding areas during lifting construction and urban areas. PhD thesis, University of Mining and Geology "St Ivan Rilski”, Sofia, 131 pp.

Toleva, Ts.S. 2019. Seismostratigraphic analysis of the Mesozoic-Tertiary section in the central part of Eastern Bulgaria. PhD thesis, University of Mining and Geology "St Ivan Rilski”, Sofia, 207 pp. Full text.

Tsvetkova, I.V. 2019. Creating a database for valuation and management of the geological heritage in North Rila for the purposes of geopark "RILA". PhD thesis, University of Mining and Geology "St Ivan Rilski”, Sofia, 149 pp. Full text.

Yovchev, D.Y. 2019. Native gold and platinum from the Eastern Stara Planina mountain. PhD thesis, Sofia University “St Kliment Ohridski”, 212 pp. Full text.

\section{8}

Apostolova, D.T. 2018. Characteristics of biomarkers and polycyclic aromatic hydrocarbons in coals with different rank and fly ashes from Bulgarian thermoelectric power plants. PhD thesis, Sofia University "St Kliment Ohridski”, 139 pp. Full text.

Dobrev, M.D. 2018. Influence of post-ore deformations on the shape and spatial position of the ore bodies in the Chelopech deposit. PhD thesis, University of Mining and Geology “St Ivan Rilski”, Sofia, 125 pp. Summary.

Donkova, Y.A. 2018. Quaternary sediments in the Sofia basin and their relation to Holocene faults. $\mathrm{PhD}$ thesis, Geological Institute, Bulgarian Academy of Sciences, Sofia, 190 pp. Summary.

Dotseva, Z.A. 2018. Mechanisms of formation, evolution, neotectonic and risk processes in part of the extensional basins in the Central Stara Planina Mountain. PhD thesis, Sofia University "St Kliment Ohridski”, 273 pp. Summary.

Gerginov, P.N. 2018. Hydrogeological conditions in the area of NPP “Kozloduy”. PhD thesis, Geological Institute, Bulgarian Academy of Sciences, Sofia, 126 pp. Summary.

Ilieva, E.S. 2018. Geology of Golo Bardo. PhD thesis, University of Mining and Geology "St Ivan Rilski”, Sofia, 200 pp. Full text.

Koleva, K. 2018. GIS model and database for estimation and management of flood risk in the Tundzha lowering. $\mathrm{PhD}$ thesis, University of Mining and Geology “St Ivan Rilski”, Sofia, $135 \mathrm{pp}$.

Nachev, G.N. 2018. Tectonomorphologic characteristics and geographic information analysis of soil formations from the Tundja structural trough. $\mathrm{PhD}$ thesis, University of Mining and Geology “St Ivan Rilski”, Sofia, 123 pp. Summary.
Tchakalova, B.I. 2018. Engineering barriers of plastic loesscement mixtures for waste isolation. $\mathrm{PhD}$ thesis, Geological Institute, Bulgarian Academy of Sciences, Sofia, 135 pp. Full text.

\section{7}

Anastasova, E.N. 2017. Electron microscopy study of REETh-U-bearing accessory minerals and products of their alteration from the Igralishte granite pluton (Southwestern Bulgaria). PhD thesis, Institute of Mineralogy and Crystallography, Bulgarian Academy of Sciences, Sofia, 108 pp. Summary.

Barbov, B.Zh. 2017. Synthesis of zeolite Beta and zeolite NaX in the presence of seeds. $\mathrm{PhD}$ thesis, Institute of Mineralogy and Crystallography, Bulgarian Academy of Sciences, Sofia, 95 pp. Summary.

Fotev, D.P. 2017. Engineering geological analysis and comparative assessment of Bulgarian crushed-rock aggregates utilized in railway construction. $\mathrm{PhD}$ thesis, Geological Institute, Bulgarian Academy of Sciences, 156 pp. Summary.

Metodiev, S.M. 2017. Geological position and geochemical characteristics of $\mathrm{Au}-\mathrm{Ag}-\mathrm{W}$ deposits associated with the Ruy pluton. PhD thesis, Geological Institute, Bulgarian Academy of Sciences, Sofia, 156 pp. Summary.

Prodanov, B.K. 2017. Seabed mapping of the Bulgarian continental shelf in front of the Avren Plateau coastal area for habitat classification. $\mathrm{PhD}$ thesis, Institute of Oceanology, Bulgarian Academy of Sciences, Varna, 162 pp.

Vasileva, T.M. 2017. Estimating the groundwater recharge in mountainous terrains on the example of the Lefedzha River catchment area from the Yantra River basin. $\mathrm{PhD}$ thesis, Geological Institute, Bulgarian Academy of Sciences, Sofia, 211 pp. Summary.

Velev, S.P. 2017. Petrology of volcanic complexes in the Western Srednogorie. PhD thesis, Sofia University "St Kliment Ohridski”, 200 pp, Summary.

Vlahov, A.K. 2017. Complex characteristics and genesis of graphite from the central and eastern Rhodopes. $\mathrm{PhD}$ thesis, Geological Institute, Bulgarian Academy of Sciences, Sofia, 372 pp. Summary.

\section{6}

Krastanov, M.I. 2016. Engineering geological characteristics of the landslides southwest of the city of Dzhebel, Eastern Rhodopes. PhD thesis, Geological Institute, Bulgarian Academy of Sciences, Sofia, 158 pp. Summary.

Nikolov, A.N. 2016. Geopolymers based on natural zeolite designed for construction applications: composition, structure and properties. $\mathrm{PhD}$ thesis, University of Architecture, Building and Geodesy, Sofia, 185 pp.

Sachkov, D.G. 2016. Methods for three-dimensional geometrical modeling of geological bodies with CAD and GIS applications. PhD thesis, University of Mining and Geology "St Ivan Rilski”, Sofia, 186 pp.

Valcheva-Georgieva, I.J. 2016. Biostratigraphical analysis and palaeoecological of the quaternary sequences of the Bulgarian sector of the Black Sea. PhD thesis, Institute of Oceanology, Bulgarian Academy of Sciences, Varna, 167 pp.

\section{5}

Atanasova-Vladimirova, S.V. 2015. Petrology and geochemistry of the Vitosha pluton. $\mathrm{PhD}$ thesis, Geological Institute, Bulgarian Academy of Sciences, Sofia, 154 pp. Summary. 
Jimsheladze, T. 2015. Hydrogeological investigations related to seismic activity on the territory of Georgia. $\mathrm{PhD}$ thesis, Geological Institute, Bulgarian Academy of Sciences, Sofia, 144 pp. Summary.

Nicolova-Nacheva, M. V. 2015. Remediation of mining areas polluted with toxic elements. $\mathrm{PhD}$ thesis, University of Mining and Geology “St Ivan Rilski”, Sofia, 173 pp.

Sabeva, R.N. 2015. Milin Kamak gold deposit, western Srednogorie: alteration, mineral composition, genesis. $\mathrm{PhD}$ thesis, Sofia University "St Kliment Ohridski”, 180 pp. Summary.

Stanchev, H.S. 2015. Geoinformation system of the Bulgarian sector of the Black Sea and its coastal zone. PhD thesis, Institute of Oceanology, Bulgarian Academy of Sciences, Sofia, $180 \mathrm{pp}$.

Tzvetanova, Y.K. 2015. Crystal-chemical and structural characteristics of minerals from skarns in the Zvezdel pluton. $\mathrm{PhD}$ thesis, Institute of Mineralogy and Crystallography, Bulgarian Academy of Sciences, Sofia, 183 pp. Summary.

Vidinli, B.N. 2015. Mineralogy and genesis of gold-polymetallic Srebren deposit and Pisani skali occurrence, Western Rhodopes. PhD thesis, Sofia University "St Kliment Ohridski”, 197 pp. Summary.

\section{4}

Andreeva, N.L. 2014. Geochemical and mineralogical features of shallow mountain soil from the highest part of the Vitosha Mountain and relation with the parent rock. $\mathrm{PhD}$ thesis, Sofia University “St Kliment Ohridski”, 161 pp. Summary.

Filipov, P.R. 2014. Petrology, geochemistry and geochronology of the Mesta volcanic complex and the Central Pirin batholith. PhD thesis, Geological Institute, Bulgarian Academy of Sciences, Sofia, $254 \mathrm{pp}$. Full text.

Ganev, V.Y. 2014. LA-ICP-MS analytical approach for isotope studies of solid-state geological objects. $\mathrm{PhD}$ thesis, Institute of Mineralogy and Crystallography, Bulgarian Academy of Sciences, Sofia, 134 pp. Summary.

Georgieva, S.K. 2014. Mineralogy and zonal development of hydrothermal alteration in the Chelopech deposit and relation to the ore mineralization. $\mathrm{PhD}$ thesis, Geological Institute, Bulgarian Academy of Sciences, Sofia, 167 pp. Summary.

Granchovski, G.M. 2014. Nannofossil biostratigraphy of the Upper Cretaceous in the Kula Zone. PhD thesis, Geological Institute, Bulgarian Academy of Sciences, Sofia, 421 pp. Summary.

Grozdev, V.Y. 2014. Isotope-geochemical and geochronological characteristic of the Tertiary magmatism in the Kyustendil Region (Bulgaria) and Kratovo area (FYR Macedonia). PhD thesis, Geological Institute, Bulgarian Academy of Sciences, Sofia, $247 \mathrm{pp}$. Summary.

Ivanova, I.G. 2014. Mineralogy and geochemistry of stream sediments from the Ogosta dam lake and its catchment basin. PhD thesis, Sofia University "St Kliment Ohridski", 171 pp. Summary.

Kotsev, I.S. 2014. Structure, dynamics and regionalization of the landscape complexes between cape Kaliakra and cape Emine, Bulgarian Black Sea coastal zone. PhD thesis, Institute of Oceanology, Bulgarian Academy of Sciences, Varna, 302 pp.

Peev, P. 2014. Palaeogeography of the harbour basins in the ancient marine history and archaeology along the Western Black Sea. PhD thesis, Institute of Oceanology, Bulgarian Academy of Sciences, Varna, 265 pp.

Seferinov, S.D. 2014. Planktonic foraminifera and biostratigraphy of the Paleogene System in part of the Lom Depression. PhD thesis, Sofia University "St Kliment Ohridski", 282 pp. Summary.
Trifonova, E.V. 2014. Numerical modelling of beach and bottom slope deformations. PhD thesis, Institute of Oceanology, Bulgarian Academy of Sciences, Varna, 135 pp.

Bozhinova-Haapanen, A.B. 2014. Engineering geological characteristic of Sofia basin clays in view of geotechnical constructions. PhD thesis, University of Mining and Geology “St Ivan Rilski”, Sofia, 118 pp.

\section{3}

Hikov, A.G. 2013. Geochemistry of advanced argillic alteration zones of deposits from the Srednogorie and Rhodopes regions. $\mathrm{PhD}$ thesis, Geological Institute, Bulgarian Academy of Sciences, Sofia, 262 pp. Summary.

Jelev, G.N. 2013. Study of the volcanic structures in the area of the eastern Rhodopes through remote sensing and GIS. $\mathrm{PhD}$ thesis, Space Research and Technology Institute, Bulgarian Academy of Sciences, Sofia, 120 pp.

Raicheva, R.V. 2013. Role of magma mixing processes in the petrological evolution of the Zvezdel palaeovolcano. $\mathrm{PhD}$ thesis, Geological Institute, Bulgarian Academy of Sciences, Sofia, 176 pp. Summary.

Tacheva, E.S. 2013. Mineralogical and geochemical characteristics of accessory minerals from the Petrohan pluton. $\mathrm{PhD}$ thesis, Institute of Mineralogy and Crystallography, Bulgarian Academy of Sciences, Sofia, 139 pp. Summary.

\section{2}

Ivanov, I.Y. 2012. Analysis and assessment of the hazard of ground collapses in the Kameno Pole-Karlukovo karst area. $\mathrm{PhD}$ thesis, Geological Institute, Bulgarian Academy of Sciences, Sofia, 164 pp. Summary.

Stefanov, Y.N. 2012. Sedimentology of the Paleogene rocks from the Padesh basin, southwestern Bulgaria. $\mathrm{PhD}$ thesis, Sofia University “St Kliment Ohridski”, 205 pp.

\section{1}

Balkanska, E.M. 2011. Structure and emplacement mechanisms of the Botev Vrah thrust, Central Stara Planina Mountain. $\mathrm{PhD}$ thesis, Sofia University “St Kliment Ohridski”, 238 pp. Summary.

Beratis, I.A. 2011. Stratigraphy and depositional environments of the Neogene sediments in the Struma Basin, Northern Greece. PhD thesis, Sofia University "St Kliment Ohridski”, 179 pp. Summary.

Botoucharov, N.D. 2011. Basin analysis and source rock assessment of Triassic sediments in the South Moesian Platform margin (between the Iskar and Yantra rivers). $\mathrm{PhD}$ thesis, Sofia University "St Kliment Ohridski”, 235 pp. Summary.

Kiselinov, H.B. 2011. Tectonic structure and evolution of the Sredogriv metamorphics. PhD thesis, Geological Institute, Bulgarian Academy of Sciences, Sofia, 215 pp. Summary.

Petrova, S.D. 2011. Ammonite and calpionellid biostratigraphy of the Berriasian, Valanginian and Hauterivian stages from the Western Srednogorie and Western Balkan Mountains. $\mathrm{PhD}$ thesis, Geological Institute, Bulgarian Academy of Sciences, Sofia, 353 pp. Summary.

Ruskov, K.I. 2011. Geology and geostatistical models of ore bodies in the Zidarovo ore field. $\mathrm{PhD}$ thesis, University of Mining and Geology "St Ivan Rilski”, Sofia, 223 pp.

Terziyska, L.D. 2011. Powder X-ray diffraction study of clinoptilolite modified by ion-exchange and occlusion. $\mathrm{PhD}$ thesis, Institute of Mineralogy and Crystallography, Bulgarian Academy of Sciences, Sofia, 107 pp. 
Zdravkov, A.K. 2011. Petrological and geochemical features of coals and coal-bearing rocks from the Beli Breg and Stanyantsi basins. PhD thesis, University of Mining and Geology “St Ivan Rilski”, Sofia, 311 pp.

\section{0}

Andreeva, P.V. 2010. Microfacies analysis of Devonian carbonate and evaporite rocks in deep wells from Northeastern Bulgaria. PhD thesis, Geological Institute, Bulgarian Academy of Sciences, Sofia, 210 pp. Summary.

Dimitrov, H.B. 2010. Seismostratigraphic analysis (sequence and lithofacial architecture) in respect to the oil and gas assessment of the nearshore part of the Dolna Kamchia sedimentary basin. PhD thesis, University of Mining and Geology “St Ivan Rilski”, Sofia, 196 pp.

Katsarov, M.N. 2010. Geological structure, composition and genesis of the zeolite deposits in the North-eastern Rhodopes. $\mathrm{PhD}$ thesis, University of Mining and Geology "St Ivan Rilski”, Sofia, 210 pp.

Naydenov, K.V. 2010. Structure of the Maritsa strike-slip shear zone in the area between the towns of Kostenets and Krichim, Bulgaria. PhD thesis, Sofia University "St Kliment Ohridski”, 165 pp.

\section{9}

Dimitrova, D.A. 2009. Mineralogy of the ore deposits and occurrences in the Chiprovtsi ore zone. $\mathrm{PhD}$ thesis, Geological Institute, Bulgarian Academy of Sciences, Sofia, 248 pp.

Dochev, D.I. 2009. Inoceramid and ammonite fauna and biostratigraphy of the Turonian-Santonian interval in part of the Western Srednogorie. $\mathrm{PhD}$ thesis, Sofia University "St Kliment Ohridski”, 320 pp.

Kadiyski, M.K. 2009. Dehydratation behaviour of ion-exchanged and natural heulandite: an X-ray single crystal study. PhD thesis, Institute of Mineralogy and Crystallography, Bulgarian Academy of Sciences, Sofia, 283 pp.

Raeva, E.D. 2009. Geochemistry of granites and metagranites from the upper Arda River valley, Central Rhodopes, Bulgaria. PhD thesis, Sofia University "St Kliment Ohridski”, 216 pp.

Stefanova, E.S. 2009. Genetic features of quartz from the Elatsite porphyry copper deposit. $\mathrm{PhD}$ thesis, Sofia University "St Kliment Ohridski”, 157 pp.

\section{8}

Dimitrov, D.P. 2008. Genesis, properties and application of deep sea organogenic-mineral sediments from the Western part of the Black Sea bottom. PhD thesis, Institute of Oceanology, Bulgarian Academy of Sciences, Varna, 229 pp.

Kostov, K.S. 2008. Indices of palaeoseismicity in karst terrains. $\mathrm{PhD}$ thesis, Geological Institute, Bulgarian Academy of Sciences, Sofia, 191 pp.

Velichkova-Keskinova, N.S. 2008. Investigations on the possibilities for improvement of the analytical characteristics of ICP-AES in the analysis of environmental materials and geological samples. PhD thesis, Geological Institute, Bulgarian Academy of Sciences, Sofia, 117 pp.

\section{7}

Dencheva, S.K. 2007. Experimental study on genesis of natural layered double hydroxides. $\mathrm{PhD}$ thesis, Sofia University "St Kliment Ohridski”, 183 pp.
Ilieva, A.V. 2007. Crystallochemical and structural features of natural and modified montmorillonites from Bulgarian deposits of bentonite clays. $\mathrm{PhD}$ thesis, Institute of Mineralogy and Crystallography, Bulgarian Academy of Sciences, Sofia, 127 pp.

Lazarova, A.V. 2007. Structure, emplacement mechanisms and tectonic position of the Vezhen pluton, Central Stara Planina Mts. PhD thesis, Sofia University "St Kliment Ohridski”, 180 pp.

Tzankova, N.S. 2007. Morphology and crystal chemistry of garnets from the metamorphic rocks in the frame of the Sakar pluton, SE Bulgaria. PhD thesis, University of Mining and Geology “St Ivan Rilski”, Sofia, 211 pp.

\section{6}

Atanassova, R.G. 2006. Hydrothermal minerals in highly nonequilibrium conditions: Morphology and crystal growth of hydrothermal sulphides far from the equilibrium. $\mathrm{PhD}$ thesis, Geological Institute, Bulgarian Academy of Sciences, Sofia, 148 pp.

Mihailova, V.P. 2006. Engineering geological zoning of the town of Silistra. PhD thesis, Geological Institute, Bulgarian Academy of Sciences, Sofia, 135 pp.

Mitev, I.G. 2006. Subfossil fauna of birds and mammals (Aves et Mammalia, Vertebrata) from localities in Northeastern Bulgaria. PhD thesis, National Museum of Natural History, Bulgarian Academy of Sciences, Sofia, 119 pp.

Titorenkova, R.H. 2006. Mineralogical features of zircon from Paleozoic metagranites from the Ograzhden Mountain, Serbo-Macedonian massif, SW Bulgaria. PhD thesis, Institute of Mineralogy and Crystallography, Bulgarian Academy of Sciences, Sofia, 149 pp.

\section{5}

Aidanlijsky, G.K. 2005. Facies, sedimentary environments and stratigraphy of the Petrohan Terrigenous Group in part of the Western Stara Planina. PhD thesis, University of Mining and Geology “St Ivan Rilski”, Sofia, 198 pp.

Dyulgerov, M.M. 2005. Potassic-alkaline magmatism from the Stara Planina Mountain, Bulgaria: petrological study of Buhovo-Seslavtsi, Svidnya and Shipka complexes. PhD thesis, Sofia University “St Kliment Ohridski”, 310 pp.

Ferdov, S.L. 2005. Synthesis and crystallochemical characteristics of microporous titanosilicates. $\mathrm{PhD}$ thesis, Institute of Mineralogy and Crystallography, Bulgarian Academy of Sciences, Sofia, 143 pp.

Markov, G.N. 2005. The fossil proboscideans of Bulgaria. PhD thesis, National Museum of Natural History, Bulgarian Academy of Sciences, Sofia, 225 pp.

Ovtcharova, M.N. 2005. Petrology, geochronology and isotope study of metagranitoids from the eastern part of the Madan-Davidkovo dome structure. $\mathrm{PhD}$ thesis, Sofia University "St Kliment Ohridski”, 189 pp.

\section{4}

Georgiev, N.A. 2004. Structure and emplacement conditions of granitoid bodies from the south and southeast parts of the Ihtimanska Sredna Gora. PhD thesis, Sofia University "St Kliment Ohridski”, 215 pp.

Georgieva, M.G. 2004. Geochemical criteria for correlation of orthogneisses from the Central Rhodopes. PhD thesis, Geological Institute, Bulgarian Academy of Sciences, Sofia, $192 \mathrm{pp}$. 
Kostova, B.V. 2004. Fluid inclusions in quartz from the Yuzhna Petrovitsa lead-zinc deposit, Madan ore field. $\mathrm{PhD}$ thesis, Sofia University "St Kliment Ohridski”, 158 pp.

Nikolova, R.P. 2004. Structural characteristics of the compounds of the systems $\mathrm{M}(\mathrm{ReO})_{2}-\mathrm{L}-\mathrm{H}_{2} \mathrm{O}, \mathrm{M}=\mathrm{Ca}, \mathrm{Sr}, \mathrm{Ba}$, $\mathrm{Pb}, \mathrm{Cd}$ and $\mathrm{L}=\mathrm{CO}\left(\mathrm{NH}_{2}\right)_{2}, \mathrm{CS}\left(\mathrm{NH}_{2}\right)_{2}$. PhD thesis, Institute of Mineralogy and Crystallography, Bulgarian Academy of Sciences, Sofia, 108 pp.

Petrov, V.P. 2004. Hydrogeology of the Pliocene aquifer complex on the territory of the Sofia Valley. $\mathrm{PhD}$ thesis, University of Mining and Geology "St Ivan Rilski”, Sofia, 155 pp.

Slavova, K.R. 2004. Climatic and geocatastrophic events in the Black Sea 7500 calendar years BP. PhD thesis, Institute of Oceanology, Bulgarian Academy of Sciences, Varna, 135 pp.

Stoyanov, N.T. 2004. Estimation and prognostication of groundwater pollution caused by sanitary landfills. $\mathrm{PhD}$ thesis, University of Mining and Geology "St Ivan Rilski”, Sofia, 205pp.

Stoykov, S.S. 2004. Petrology of the Late Cretaceous magmatism in the region of Chelopech, Central Srednogorie magmatic zone. PhD thesis, Geological Institute, Bulgarian Academy of Sciences, Sofia, $137 \mathrm{pp}$.

Stoynev, S.B. 2004. Liquefaction of saturated sands: assessment, prognosis, management and protection. $\mathrm{PhD}$ thesis, University of Mining and Geology "St Ivan Rilski”, Sofia, $158 \mathrm{pp}$

\section{3}

Dimitrov, L.I. 2003. Shallow gas and seabed gas events of the Bulgarian offshore. PhD thesis, Institute of Oceanology, Bulgarian Academy of Sciences, Varna, 220 pp.

Ivanov, P.G. 2003. Engineering-seismogeological conditions of the Sofia Kettle. PhD thesis, Geological Institute, Bulgarian Academy of Sciences, Sofia, $166 \mathrm{pp}$.

Ivanova, R.I. 2003. Petrology of the acid volcanic rocks from the Sheynovets caldera, Eastern Rhodopes. PhD thesis, Geological Institute, Bulgarian Academy of Sciences, Sofia, $173 \mathrm{pp}$.

Petkov, I.S. 2003. Analysis and assessment of the degree of groundwater pollution with heavy metals in the Plovdiv region. $\mathrm{PhD}$ thesis, Geological Institute, Bulgarian Academy of Sciences, Sofia, $152 \mathrm{pp}$.

Popov, K.P. 2003. Geology and geochemical models of the Radka ore district. PhD thesis, University of Mining and Geology “St Ivan Rilski”, Sofia, 182 pp.

Stoyanova, V.I. 2003. Lower Cretaceous scleractinian corals from part of the Central Fore-Balkan (taxonomy and reef buildups). PhD thesis, Sofia University "St Kliment Ohridski”, 312 pp.

Vassileva, Ch.G. 2003. Phase-mineral transformations and chemical interactions in inorganic matter during combustion of Bulgarian coals. PhD thesis, Institute of Mineralogy and Crystallography, Bulgarian Academy of Sciences, Sofia, $187 \mathrm{pp}$.

\section{2}

Antonov, D.I. 2002. Loess near Kozloduy NPP as a medium for low and intermediate level radioactive waste disposal. $\mathrm{PhD}$ thesis, Geological Institute, Bulgarian Academy of Sciences, Sofia, $166 \mathrm{pp}$.

Bonev, N.G. 2002. Regional geology and geodynamic evolution of the eastern Circum-Rhodope belt, Bulgaria-Greece. $\mathrm{PhD}$ thesis, Sofia University “St Kliment Ohridski”, 181 pp.

Hristov, V.H. 2002. A study on hydrothermal fields and thermal aquifers in Southern Bulgaria by application of chemical geothermometers and helium method. $\mathrm{PhD}$ thesis, Geological Institute, Bulgarian Academy of Sciences, Sofia, 187 pp.

Metodiev, L.S. 2002. The Toarcian in a part of the Stara Planina Mts and the Fore-Balkan - ammonite taxonomy and biostratigraphy. $\mathrm{PhD}$ thesis, Sofia University "St Kliment Ohridski”, 300 pp.

Radulov, A.G. 2002. Quaternary karst in the valley of the Rusenski Lom River and its tributaries. $\mathrm{PhD}$ thesis, Geological Institute, Bulgarian Academy of Sciences, Sofia, 197 pp. Summary.

Valchev, B.V. 2002. Deep sea benthic foraminifera from the coastal part of the east Stara Planina Mountains. PhD thesis, Sofia University "St Kliment Ohridski”, 240 pp.

Vassileva, R.D. 2002. Manganoan skarns from the Central Rhodopian $\mathrm{Pb}-\mathrm{Zn}$ deposits. $\mathrm{PhD}$ thesis, Geological Institute, Bulgarian Academy of Sciences, Sofia, 215 pp.

\section{1}

Ichev, M.M. 2001. Lateral lithofacial variability of the Precambrian volcanigenic-sedimentary formations from the Central Rhodopes. PhD thesis, Geological Institute, Bulgarian Academy of Sciences, Sofia, $174 \mathrm{pp}$.

Ivanova, Ts.S. 2001. Crystal chemical peculiarities and thermal decomposition of minerals from the hydrotalcite group. PhD thesis, Sofia University "St Kliment Ohridski”, 107 pp.

Nikolov, P.I. 2001. Marine molluscan fauna from the Karapelit, Galata and Euxinograd formations (Neogene, Middle Miocene), Northeastern Bulgaria. Taxonomy, stratigraphical significance, palaeozoogeography and palaeoecology. $\mathrm{PhD}$ thesis, Geological Institute, Bulgarian Academy of Sciences, Sofia, 240 pp.

Tarassov, M.P. 2001. Alteration of scheelite and formation of secondary tungsten and tungsten-iron minerals under supergene conditions. $\mathrm{PhD}$ thesis, Institute of Mineralogy and Crystallography, Bulgarian Academy of Sciences, Sofia, 187 pp.

Vangelov, D.A. 2001. Stratigraphic aspects of the basin analysis - an example from the Upper Cretaceous-Paleogene sedimentary records of the East Balkans and surrounding areas. PhD thesis, Sofia University "St Kliment Ohridski", 273 pp.

Yaneva, M.I. 2001. Sedimentology of Neogene deposits in the Sofia Basin. PhD thesis, Geological Institute, Bulgarian Academy of Sciences, Sofia, 191 pp.

Yossifova, M.G. 2001. Petrographical, mineralogical and inorganic chemical composition of coal and their solid wastes from Preparation Plants "Tvarditsa", "Pernik" and "Bobov Dol". PhD thesis, Sofia University "St Kliment Ohridski”, 199 pp.

\section{0}

Vangelova, V.E. 2000. Mineralogy, geochemistry and genetic features of deposits in the Spahievo ore field, Eastern Rhodopes. $\mathrm{PhD}$ thesis, Sofia University "St Kliment Ohridski", $186 \mathrm{pp}$.

Vasilev, E.G. 2000. Geology of the central Strandzha Mountain. PhD thesis, Geological Institute, Bulgarian Academy of Sciences, Sofia, $226 \mathrm{pp}$.

Ilieva, T.K. 2000. Late Cretaceous and Danian echinoids of the suborder Spatangacea from Northern Bulgaria - taxonomy and stratigraphic significance. $\mathrm{PhD}$ thesis, University of Mining and Geology “St Ivan Rilski”, Sofia, 254 pp.

Editorial Board 